\title{
Popular Music and Society
}

\section{Popular Music, Cultural Memory, and Heritage}

\section{Andy Bennett \& Susanne Janssen}

To cite this article: Andy Bennett \& Susanne Janssen (2016) Popular Music, Cultural Memory, and Heritage, Popular Music and Society, 39:1, 1-7, DOI: 10.1080/03007766.2015.1061332

To link to this article: http://dx.doi.org/10.1080/03007766.2015.1061332

曲 Published online: 21 Dec 2015.

Submit your article to this journal ¿

LIII Article views: 1068

Q View related articles ¿

View Crossmark data \ulcorner 


\title{
Popular Music, Cultural Memory, and Heritage
}

\author{
Andy Bennett and Susanne Janssen
}

The purpose of this special edition of Popular Music and Society is to bring together a series of articles from an international group of scholars who consider, in particular and locally specific ways, how popular music has become an object of memory and, in turn, a focus for contemporary renditions of history and cultural heritage. Popular music's links to and evocation of the past have been evident for many years. Frith has highlighted popular music's inherently nostalgic properties, a point reinforced by DeNora in her highly instructive work on the propensity of music both to link individuals with their past and to emotionally ground them in the present. In an everyday sense, the untimely deaths of rock and pop icons such as Elvis Presley, John Lennon, and Kurt Cobain have triggered mass mourning that forcibly demonstrates the extent to which such artists come to signify the complex interplay of generational identification and collective generational memory (Gregory and Gregory; Elliott; Strong). However, it is not just popular music artists themselves but rather the vast array of music-related objects, images, texts, and places that become inscribed with memory (Bennett and Rogers, "In Search," "In the Scattered") by music fans and members of specific music scenes. While the study of cultural consumption is well established (see, for example, Miller; Dant; Woodward) in the field of popular music studies, a focus on memory and heritage is less so given the dominant emphasis in scholarship on artists, texts, performance, media, and industry. There are some notable exceptions, such as Waksman's highly innovative work on the electric guitar and Hayes's study of vinyl records. Similarly, there is an emerging focus on technological artifacts of popular music history (see, for example, Shuker, Wax). However, the broader field of popular music's material legacy, and its connections to cultural memory, remains largely unmapped.

A similar, if slightly more dynamic, situation obtains in relation to the significance of popular music as contemporary cultural heritage. Certainly, particular regions and cities have for a long time created robust tourist and leisure industries around their popular music histories, a notable example here being Chicago, which is an 
established destination for blues enthusiasts (Grazian). It is only in relatively recent times, though, that a broader heritage boom has taken hold of popular music, particularly in relation to its sociohistorical significance in a post-1945 context. Prior to this, the term, and indeed aesthetic understanding of, heritage was not readily applied to popular music and other aspects of contemporary popular culture, such as cinema, television, and popular literature, whose mass-produced, commercial, and global properties were considered to render them the antithesis of authentic cultural value as this is conceived and practiced within more conventional interpretations of heritage. Similarly, a significant level of institutional bias served to block the incorporation of contemporary popular cultural forms into heritage discourse (Brandellero and Janssen). This is seen, for example, in the way in which state subsidy for the arts and culture has generally been directed towards more high-brow manifestations of the latter. As Shuker observes, "Popular culture' is then constructed in opposition to this, as commercial, inauthentic, and so unworthy of government support" (Understanding 68).

Such high culture/low culture distinctions are, however, becoming increasingly unsustainable in the context of late modernity, where aspects of "high" and "low"/ popular culture frequently merge (Bennett, Culture; Janssen, Verboord, and Kuipers). Aligned with this has been a shift in perception among ageing music audiences who now consider rock, indie, punk, and other genres "not merely as something particular to their youth, but rather as a key element in their collective cultural awareness and a major contributor to their generational identity" (Bennett, "Heritage" 478). Indeed, notwithstanding the tensions that continue to exist between popular music and notions of heritage, during the last two decades there has been an increasing push, first and foremost in the UK and USA, but also in other European countries, to archive and celebrate the history of popular music and to re-present it as a pivotal aspect of contemporary cultural heritage (Bennett, Music; Brandellero and Janssen). This has been achieved through a range of mediums, from organized tours of music-related sites and spaces, notably the various Beatles tours available in Liverpool (Cohen), through the establishment of permanent museums or temporary exhibitions focusing on aspects of contemporary popular music history (Leonard; Leonard and Knifton; Van der Hoeven), to the consecration of buildings with significant connections to the history of popular music, for example, the childhood homes of John Lennon and Paul McCartney in Liverpool or Sun Studio in Memphis (where Elvis Presley made his early recordings) (Gibson). The importance of recognizing the contribution of popular music to contemporary notions of cultural heritage has been variously emphasized in relation to a number of issues, including its connectedness to understandings of local and national identity and its relevance for regional and urban regeneration through, for example, the promotion of cultural tourism (Brandellero and Janssen; Connell and Gibson; Baker, Bennett, and Homan).

The featured articles in this special edition are drawn from the research findings of two sister projects, funded respectively by the Australian Research Council ${ }^{1}$ and the Humanities in the European Research Area. ${ }^{2}$ Between 2010 and 2013, these projects 
examined the connections among popular music, cultural memory, and heritage across a range of countries including Australia, Austria, Iceland, Israel, the Netherlands, Slovenia, the UK, and the USA. In each of these places, both official and unofficial renderings of popular music history and heritage were studied to gauge their impact on both the ways in which popular music is being represented as an aspect of national cultural identity and its place within the collective cultural memory of local popular music audiences.

The number of archives now dedicated to popular music, in its myriad forms, is growing internationally and at an exponential rate. Such archives range from wellknown and established sites, such as the British Library Sound Archive, in London, and the National Film and Sound Archive, in Canberra, Australia, through to smallscale, do-it-yourself archives subsisting on skeletal budgets and serving a niche clientele. Baker, Doyle, and Homan's article focuses on the popular music archive in an international context. Using data from interviews conducted with archive employees in Australia, Iceland, Israel, the UK, and the USA, the article considers the various challenges that present themselves for popular music archives and archivists. As Baker et al. observe, such challenges range from economic pressures, through to keeping up with new developments in technology, to the aesthetic considerations and pragmatic choices that need to be made when the ideal would be to "keep everything" but reality dictates the rationalization of archival catalogs.

As noted earlier, although some aspects of popular music's material existence have been examined in existing academic scholarship, there remains a gap in our understanding of how more mundane objects-for example, tour T-shirts, ticket stubs, posters, and various forms of music memorabilia-function at the level of individual and collective memory. Bennett and Rogers's article draws on findings from a study of popular music and materiality in various cities across Australia. As Bennett and Rogers observe, what is apparent in the way individuals describe their relationships to personal collections of popular music-related objects is their role in the figurative writing and representation of life history. Moreover, this process appears to have taken on an additional level of presence with the increasing prevalence of digital technology in the domestic space of the home. An example of this is the way that personal music collections gathered over time on various formats are either digitized or re-purchased in formats compatible with the digital archiving features of software such as iTunes and Windows Media Player.

A perhaps predictable aspect of the route that popular music has taken in achieving status as cultural heritage is that only certain artists and genres have been awarded such status by various prestige-giving bodies (see Schmutz; Schmutz et al.). Significantly, though, in a world of expanding digital media and diversifying cultural entrepreneurship, many of those artists and genres ignored in dominant, canonical discourses of popular music heritage have been rediscovered and re-presented by what Bennett ("Heritage") refers to as DIY preservationists. Dowd, Ryan, and Tai's article examines this phenomenon in relation to progressive rock, a genre that, having had its most significant commercial reach during the early to mid-1970s, rapidly lost 
credibility in the eyes of music critics due to the rise of punk and new wave. As Dowd et al. discuss, however, although progressive rock may have slipped under the mainstream commercial and critical radar, the genre has continued to develop, attracting new fans and having a resurgence in the late 1990s and early 2000s. Along with such new-found "underground" appeal, progressive rock also acquired a new level of critical attention as specialist critics began writing their own accounts of progressive rock's place as a form of cultural heritage.

A continuing factor underpinning popular music's transition to the status of cultural heritage is the competing discourses and contestations as to what counts as authentic music in particular national and local contexts. In the early 1990s, MacKinnon's compelling ethnographic study of the British folk-music scene examined how the critical and vernacular discourses of authenticity that had accumulated around popular notions of folk since the early 1960s (and given rise to the contemporary British folk club and festival scene) continue to inform perceptions of what is and is not counted as "authentic" in current practices of folk music performance and consumption. In her article on generational understandings of Slovenian music, Majsova examines the way that age and generation also come into play in determining what is characteristically understood as "local" music and how this in turn informs canonical discourses of musical authenticity in a local context. Majsova's work both examines these issues in a nation where little research exists on the relationship between aesthetic discourse and notions of authenticity and brings a new theoretical and conceptual dimension to our understanding of how such discourses are collectively constructed and articulated as social "truths."

An important aspect to bear in mind when considering popular music's place in relation to discussions of memory and heritage is that it is not merely technologically mediated texts that assume such cultural resonance. On the contrary, music written and performed within and for local communities may also become imbricated within such understandings. Reitsamer's article on the Hor 29 Novembar choir in Vienna, Austria, represents a salient case in point. Having been formed in 2009 by immigrants from the former Yugoslavia, the Hor 29 Novembar choir has asserted its place in the musical heritage of Vienna through becoming a platform for the DIY politics of the choir and its broader migrant audience. Similarly, the choir also serves as a medium for the commemoration of practices that emphasize the history of patterns of migration from the former Yugoslavia since the 1960s. Finally, as Reitsamer observes, the choir's songs also contest dominant notions of Austrian identity and the negative ways in which the mainstream represents migrants in the country. As such, Reitsamer's article also illustrates how the everyday conceptualization of "national music" and its place in local cultural heritage may often, as with understandings of musical authenticity itself, be a deeply contested and conflicted process.

The importance of language in popular music is also a factor that is often overlooked in examining how popular music becomes a marker of cultural heritage. Indeed, Bennett ("Popular") has argued that a potential "problem" with heritage discourses around music is that they continue to be predominantly rooted in 
Anglo-American constructions of authenticity and value, this also extending to the language in which rock and pop songs are performed. Although this certainly holds for the Netherlands, the dominance of English-language music and Anglo-American musical standards appears to be less taken-for-granted than it used to be in this country. In their article on the meaning of language in Dutch popular music, van der Hoeven, Janssen, and Driessen review how in recent decades the Dutch language and local Dutch dialects have become more accepted within the Dutch popular music field and are now used in a wide range of genres, with varying degrees of prestige attached to them. Van der Hoeven et al. consider how the languages of Dutch popular musicprimarily English, Dutch, and local Dutch dialects-connect with particular audiences, taste and lifestyle groups, and local communities. As van der Hoeven et al. explain, through the particular connections they form with music sung in a specific language or dialect, such groups in turn create narratives of how this music counts, or does not count, as a bona fide aspect of the broader Dutch national cultural heritage landscape.

\section{Disclosure statement}

No potential conflict of interest was reported by the authors.

\section{Funding}

This work was supported by The Australian Research Council [DP1092910] and HERA Joint Research Projects (POPID).

\section{Notes}

[1] The broader project is called "Popular Music and Cultural Memory: Localised Popular Music Histories and Their Significance for National Music Industries" and is funded under the Australian Research Council's (ARC) Discovery Project scheme for three years (2010-12, DP1092910). Chief Investigators on the project are Andy Bennett (Griffith University), Shane Homan (Monash University), Sarah Baker (Griffith University), and Peter Doyle (Macquarie University), with Research Fellow Alison Huber (Griffith University). Dr Ian Rogers (now at Royal Melbourne Institute of Technology) provided additional support for the project as a part-time research assistant.

[2] The European sister project has been supported as part of the "Popular Music Heritage, Cultural Memory and Cultural Identity" (POPID) project by the HERA Joint Research Programme (http://heranet.info/hera-joint-research-programme-1), which was co-funded by AHRC, AKA, DASTI, ETF, FNR, FWF, HAZU, IRCHSS, MHEST, NWO, RANNIS, RCN, VR and the European Community FP7 2007-2013, under the Socio-economic Sciences and Humanities programme. Principal investigators on the POPID project are Susanne Janssen (project leader, Erasmus University Rotterdam), Sarah Cohen (University of Liverpool), Peter Stankovic (University of Ljubljana), and Alfred Smudits (University of Music and Performing Arts Vienna), with postdoctoral researchers Amanda Brandellero (Erasmus University, now at the University of Amsterdam), Rosa Reitsamer (University of Music and Performing Arts, Vienna), Les Roberts (University of Liverpool), and Luka Zevnik (University of Ljubljana). 


\section{Works Cited}

Baker, Sarah, Andy Bennett, and Shane Homan. "Cultural Precincts, Creative Spaces: Giving the Local a Musical Spin.” Space \& Culture 12.2 (2009): 148-165. Print.

Bennett, Andy. Culture and Everyday Life. London: Sage, 2005. Print.

- "'Heritage Rock': Rock Music, Re-presentation and Heritage Discourse." Poetics 37.5-6 (2009): 474-489. Print.

. Music, Style and Aging: Growing Old Disgracefully? Philadelphia: Temple UP, 2013. Print.

. "Popular Music and the 'Problem' of Heritage." Sites of Popular Music Heritage. Ed.

Sara Cohen, Robert Knifton, Marion Leonard and Les Roberts. London: Routledge, 2015. Print.

Bennett, Andy and Ian Rogers. "In Search of Underground Brisbane: Music, Memory and Cultural Heritage." Sounds and the City: Popular Music, Place and Globalisation. Ed. Brett Lashua, Karl Spracklen and Stephen Wagg. Basingstoke, Hants: Palgrave, 2014. Print.

_ . "In the Scattered Fields of Memory: Unofficial Live Music Venues, Intangible Heritage and the Recreation of the Musical Past." Space \& Culture in press.

Brandellero, Amanda and Susanne Janssen. "Popular Music as Cultural Heritage: Scoping Out the Field of Practice." International Journal of Heritage Studies 20.3 (2014): 223-240. Print.

Cohen, Sara. Decline, Renewal and the City in Popular Music Culture: Beyond the Beatles. Aldershot, Hants: Ashgate, 2007. Print.

Connell, John and Chris Gibson. Sound Tracks: Popular Music, Identity, and Place. London: Routledge, 2002. Print.

Dant, Tim. Material Culture in the Social World. Buckingham: Open UP, 1999. Print.

DeNora, Tia. Music in Everyday Life. Cambridge: Cambridge UP, 2000. Print.

Elliott, Anthony. The Mourning of John Lennon. Berkeley: U of California P, 1999. Print.

Frith, Simon. "Towards an Aesthetic of Popular Music." Music and Society: The Politics of Composition, Performance and Reception. Ed. Richard Leppert and Susan McClary. New York: Cambridge UP, 1987. Print.

Gibson, Chris. "Recording Studios: Relational Spaces of Creativity in the City." Built Environment 31.3 (2005): 192-207. Print.

Grazian, David. "The Symbolic Economy of Authenticity in the Chicago Blues Scene." Music Scenes: Local, Trans-Local and Virtual. Ed. Andy Bennett and Richard A. Peterson. Nashville, TN: Vanderbilt UP, 2004. Print.

Gregory, Neal and Janice Gregory. "When Elvis Died: Enshrining a Legend." Search of Elvis: Music, Race, Art, Religion. Ed. Vernon Chadwick. Boulder, CO: Westview Press, 1997. Print.

Hayes, David. "'Take Those Old Records off the Shelf': Youth and Music Consumption in the Postmodern Age." Popular Music and Society 29.1 (2006): 51-68. Print.

Janssen, Susanne, Marc Verboord, and Giselinde Kuipers. "Comparing Cultural Classification." Kölner Zeitschrift für Soziologie und Sozialpsychologie 63.51 (2011): 139-168. Print.

Leonard, Marion. "Exhibiting Popular Music: Museum Audiences, Inclusion and Social History." Journal of New Music Research 39.2 (2010): 171-181. Print.

Leonard, Marion and Robert Knifton. "'Museums of Sound': Collecting and Curating Everyday Popular Music Experiences." Recording Leisure Lives: Everyday Leisure in Twentieth Century Britain. Ed. Robert Snape, Helen Pussard and Michael Constantine. Eastbourne, E. Sussex: Leisure Studies Association, 2012. Print.

MacKinnon, Niall. The British Folk Scene: Musical Performance and Social Identity. Buckingham: Open UP, 1994. Print.

Miller, Daniel. Material Culture and Mass Consumption. Oxford: Blackwell, 1987. Print.

Schmutz, Vaughn. "Retrospective Cultural Consecration in Popular Music." American Behavioral Scientist 48.11 (2005): 1510-1523. Print.

Schmutz, Vaughn, Alex van Venrooij, Susanne Janssen, and Marc Verboord. "Change and Continuity in Newspaper Coverage of Popular Music since 1955: Evidence from the United States, France, Germany, and the Netherlands." Popular Music and Society 33.4 (2010): 505-515. Print.

Shuker, Roy. Understanding Popular Music. 2nd edn. London: Routledge, 2001. Print. 
- Wax Trash and Vinyl Treasures: Record Collecting as a Social Practice. Aldershot, Hants: Ashgate, 2010. Print.

Strong, Catherine. Grunge: Music and Memory. Farnham, Surrey: Ashgate, 2011. Print.

Van der Hoeven, Arno. "Popular Music Memories: Places and Practices of Popular Music Heritage, Memory and Cultural Identity." Doctoral diss., Erasmus U Rotterdam, 2014. Print.

Waksman, Steve. Instruments of Desire: The Electric Guitar and the Shaping of Musical Experience. Cambridge, MA: Harvard UP, 1999. Print.

Woodward, Ian. Understanding Material Culture. London: Sage, 2007. Print.

\section{Notes on Contributors}

Andy Bennett is Professor of Cultural Sociology and Director of the Griffith Centre for Cultural Research at Griffith University in Queensland, Australia. He has authored and edited numerous books including Music, Style and Aging, Popular Music and Youth Culture, Cultures of Popular Music, Remembering Woodstock, and Music Scenes (with Richard A. Peterson). He was lead Chief Investigator on a three-year, fivecountry project funded by the Australian Research Council entitled "Popular Music and Cultural Memory" (DP1092910). He is a Faculty Fellow of the Center for Cultural Sociology, Yale University.

Susanne Janssen is Professor of Sociology of Media and Culture and Chair of the Department of Media and Communication at Erasmus University Rotterdam. She serves as the academic director of the Erasmus Research Centre for Media, Communication and Culture (ERMeCC). She has published widely on the agents and institutions involved in the creation, dissemination and valuation of literature, music and other art forms. Her current research focuses on changes and continuities in the classification of culture; the social and cultural significance of popular music heritage; processes, structures and impacts of cultural globalization; and the production and consumption of online media content. 